\title{
Comparative ultrastructure of the radiolar crown in Sabellida (Annelida)
}

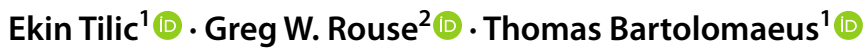

Received: 31 August 2020 / Revised: 4 November 2020 / Accepted: 17 November 2020 / Published online: 7 December 2020

(c) The Author(s) 2020

\begin{abstract}
Three major clades of tube-dwelling annelids are grouped within Sabellida: Fabriciidae, Serpulidae and Sabellidae. The most characteristic feature of these animals is the often spectacularly colorful and flower-like radiolar crown. Holding up such delicate, feathery appendages in water currents requires some sort of internal stabilization. Each of the above-mentioned family-ranked groups has overcome this problem in a different way. Herein we describe the arrangement, composition and ultrastructure of radiolar tissues for fabriciids, sabellids and serpulids using transmission electron microscopy, histology and immunohistochemistry. Our sampling of 12 species spans most of the phylogenetic lineages across Sabellida and, from within Sabellidae, includes representatives of Myxicolinae, Sabellinae and the enigmatic sabellin Caobangia. We further characterize the ultrastructure of the chordoid cells that make up the supporting cellular axis in Sabellidae and discuss the evolution of radiolar tissues within Sabellida in light of the recently published phylogeny of the group.
\end{abstract}

Keywords TEM $\cdot$ Histology $\cdot$ Fabriciidae $\cdot$ Serpulidae $\cdot$ Sabellidae

\section{Introduction}

Three family-ranked clades of tube-dwelling annelids are grouped within Sabellida (Kupriyanova and Rouse 2008): calcareous tube worms, Serpulidae Rafinesque, 1815; Sabellidae Latreille, 1825, with a mucus/sediment tube and the mostly minute Fabriciidae Rioja, 1923, as the sister group to the former two (Tilic et al. 2020). Like blooming flowers, sabellid worms extend their radiolar crowns into the water column, exposed to currents and predators (Fig. 1). In many sabellid and serpulid species, the radioles are equipped with a diverse array of radiolar eyes and photoreceptors that allow them to detect threats and withdraw rapidly into the safety of their tubes (Bok et al. 2016, 2017).

This often colorful, feathery radiolar crown is of prostomial origin and is the most characteristic feature of these three taxa, giving them their common names: fan worms and feather duster worms (Dales 1962; Fauchald 1977; Fitzhugh

Ekin Tilic

etilic@evolution.uni-bonn.de

1 Institute of Evolutionary Biology and Animal Ecology, University of Bonn, Bonn, Germany

2 Scripps Institution of Oceanography, UC San Diego, La Jolla, San Diego, CA, USA
1989; Smith 1991). The crown is used by the animal not only for respiration and suspension feeding, but can also harbor methanotrophic symbiotic bacteria in some deep-sea sabellid and serpulid species (Goffredi et al. 2020) or can sort, capture and transfer particles with its ciliated inner margins for tube building (Nicol 1931; Fitzsimons 1965; Bonar 1972). In many small species, it can collect and move sperm from the water column to epidermal spermathecae at the base of the crown, where they are stored until later fertilization of eggs (Rouse 1995, 1996a). In some sabellids and serpulids, modified radioles are even used for brooding of larvae (Gottfried 1970; Rouse 1996b). These different functions require flexibility and at the same time stiffness of the crown. In this paper, we comparatively analyze how different species fulfill these requirements of the radiolar crown that is more than just a filter-feeding device.

The radiolar crown of Sabellida is composed of two branchial lobes located laterally on either side of the mouth, proximally attaching to the anterior end of the animal. Radioles are fused distally to these lobes, and from the inner margins of each radiole paired series of ciliated pinnules branch out (Nicol 1931; Fitzhugh 1989) (Fig. 2). Holding up a delicate, feathery crown that can reach a formidable size in certain species (e.g., $>15 \mathrm{~cm}$ in length for large Sabella spalanzanii) requires an internal 
Fig. 1 Live photographs showing crown morphology in all three clades. a Fabricia stellaris (Fabriciidae), b Acromegalomma sp. Note the two modified radioles with apical compound radiolar eyes characteristic to the genus (Sabellidae). c Spirorbis spirorbis (Serpulidae), d Spirobranchus sp. (Serpulidae)
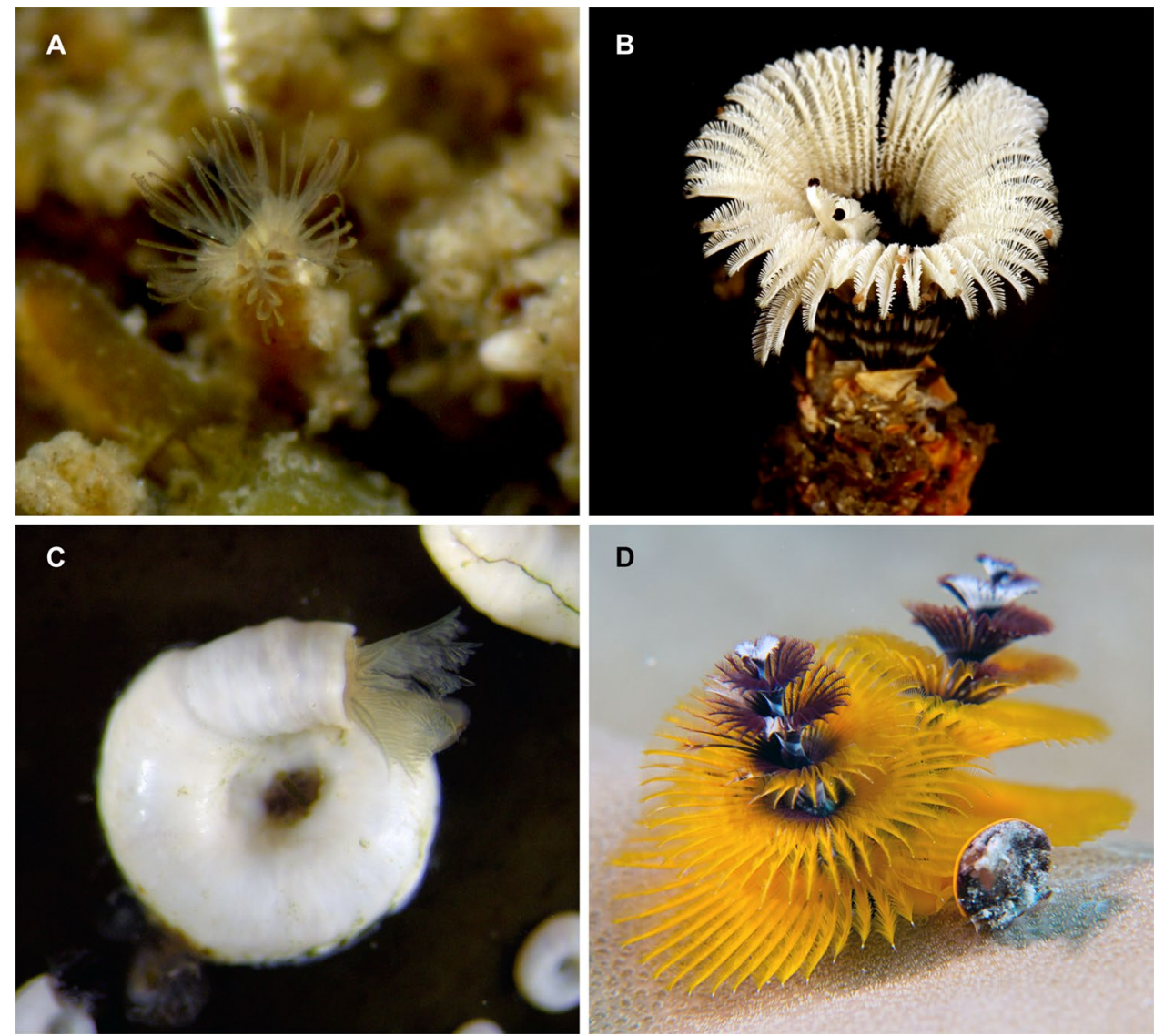

stabilization mechanism. Many authors have noted significant differences in the arrangement and composition of radiolar tissues within Sabellida: Fabriciidae and Serpulidae lack a cellular supporting axis (Hanson 1949; Rouse 1993, 1996c; Bick 2004; Randel and Bick 2012), whereas Sabellidae possess chordoid cells of varying numbers (Nicol 1931; Fitzhugh 1989; Capa et al. 2011).

The composition of this supporting cellular axis resembles cartilage and has been the focus of several morphological investigations (Krukenberg 1882; Viallanes 1885, 1886; Cole and Hall 2004a, b; Capa et al. 2011). However, other than Kryvi (1977), who focused on the fine structure of the radiolar supporting cells of Sabella spallanzanii (Gmelin, 1791) (S. penicillum sensu auct.), previous studies only used histology to investigate the radiolar structure and there is no comparative ultrastructural characterization of radiolar supporting tissues within Sabellidae. Randel and Bick's (2012) study on the ontogeny and morphology of the radiolar crown of Fabricia stellaris (Müller, 1774) is the only ultrastructural investigation for Fabriciidae and a detailed ultrastructure study of serpulid radioles is lacking altogether. Orrhage (1980) investigated the innervation of the radiolar crown in Sabellidae and Serpulidae and argued for the homology of these anterior appendages and a close phylogenetic relationship between sabellids and serpulids.
Former delineations of Sabellidae included Fabriciidae (as Fabriciinae, see Fitzhugh 1989 for background), but this was shown to be paraphyletic by Kupriyanova and Rouse (2008), and the phylogenetic relationships among the three major clades of Sabellida was most recently further refined using a phylogenomic approach (Tilic et al. 2020).

In this study, we provide a comprehensive characterization of radiolar tissues for each of the three taxa using confocal laser scanning microscopy, histology and transmission electron microscopy and discuss our results in light of the recently published phylogeny of Sabellida (Tilic et al. 2020). We investigated two species of Fabriciidae, three species of Serpulidae and six species of Sabellidae, including representatives of both sabellid subclades Myxicolinae and Sabellinae (sensu Tilic et al. 2020) and the enigmatic sabellin Caobangia brandti Jones, 1974, with its unique unicellular radiolar axis.

\section{Material and methods}

\section{Studied species}

A list of all included species with their collection localities and details on study and fixation method is provided in Table 1. 

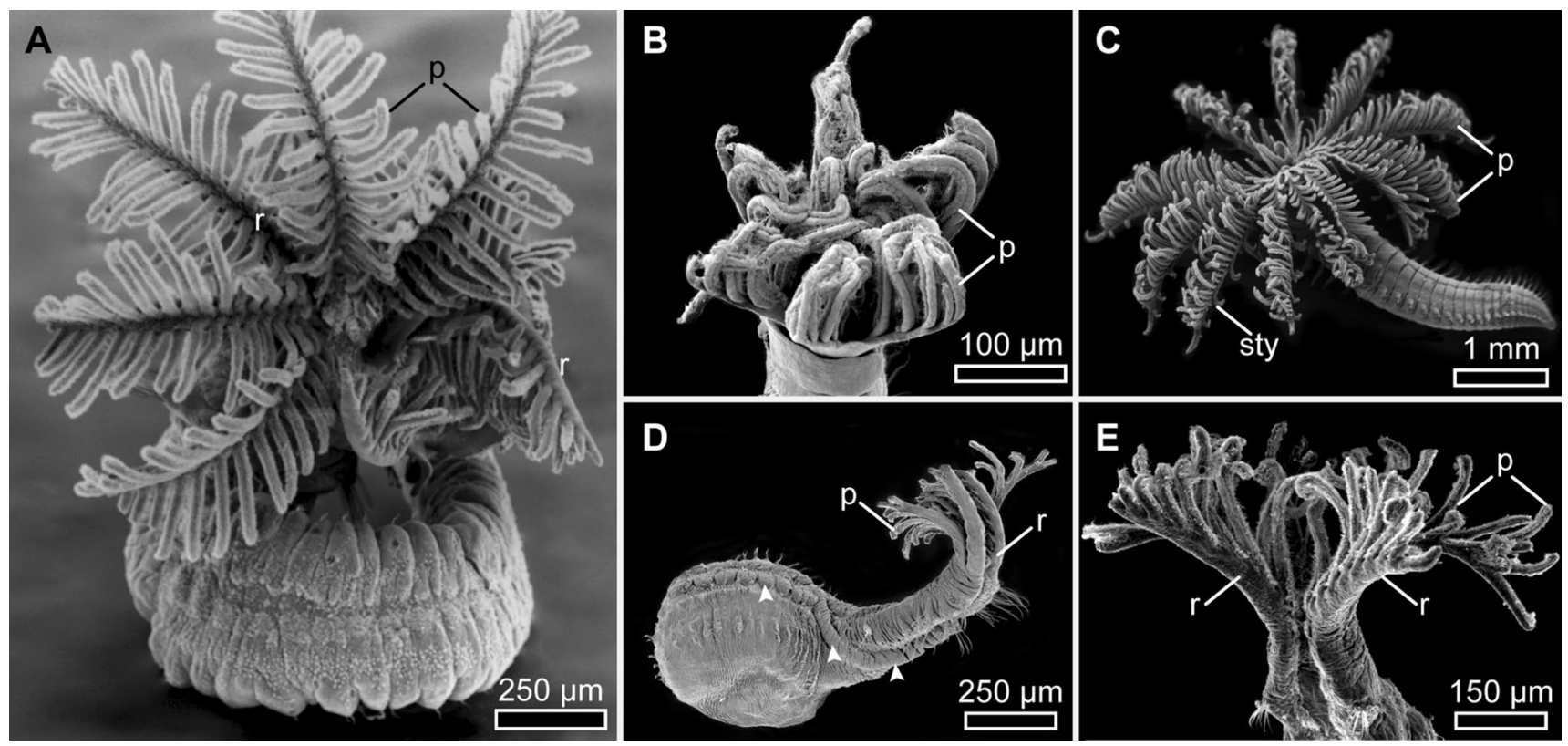

Fig. 2 SEM images showing details of the radiolar crown. a Spirorbis spirorbis (Serpulidae), b Amphicorina sp. (Sabellidae: Myxicolinae), c Branchiomma bombyx (Sabellidae: Sabellinae), d, e Caobangia

\section{Paraffin histology}

Animals were relaxed using an isotonic mix of $7 \% \mathrm{MgCl}_{2}$ with 1:1 seawater and fixed overnight in Bouin's solution (modified after Dubosque-Basil). The specimens were dehydrated completely in an ascending ethanol series, followed by an incubation in methylbenzoate and subsequently in butanol. Before the material was embedded in Paraplast (McCormick Scientific, Richmond, USA), they were preincubated in Histoplast (Thermo Scientific, Dreieich, Germany) at $60{ }^{\circ} \mathrm{C}$ for several days and multiple medium changes. Serial sections of 5 or $7 \mu \mathrm{m}$ thickness were prepared using an Autocut 2050 microtome (Reichert-Jung, Leica, Wetzlar) and transferred on to glass slides coated with albumen-glycerin. Sections were stained using either Azan staining, Masson-Goldner trichrome staining or Weigert-hematoxylin nuclear and Eosin counterstaining. Coverslips were mounted using Malinol. Any deviations from the standard histology protocols described above are noted in Table 1.

\section{Semi-thin histology and transmission electron microscopy (TEM)}

Specimens for TEM were fixed directly in $2.5 \%$ glutaraldehyde buffered in $0.05 \mathrm{M}$ phosphate $0.3 \mathrm{M} \mathrm{NaCl}$ saline (PBS) for approximately $1 \mathrm{~h}$ (at room temp.). Animals were not relaxed with $\mathrm{MgCl}_{2}$ to avoid osmolarity artifacts and brandti (Sabellidae: Sabellinae). Arrowheads mark the coiled gut, terminating near the head, $p$ pinnule, $r$ radiole, sty stylode

ruthenium red was added to the fixative to improve the staining of the extracellular matrix and basal lamina (Minuth and Denk 2015). The specimens were rinsed several times in buffer and postfixed in $1 \% \mathrm{OsO} 4$ buffered in $0.05 \mathrm{M}$ phosphate $0.3 \mathrm{M} \mathrm{NaCl}$ saline for $30 \mathrm{~min}\left(\right.$ at $4{ }^{\circ} \mathrm{C}$ ). $0.1 \mathrm{M}$ sodium cacodylate was used as a buffer during some fixations instead of PBS (Table 1). The material was subsequently dehydrated in an ascending acetone series and embedded in either Araldite or Spurr's resins. Transverse sections of complete radiolar crowns (for minute species) or single radioles were sectioned into $1 \mu \mathrm{m}$ semi-thin sections using a Diatome Histo $45^{\circ}$ diamond knife, stained with toluidine blue (1\% toluidine, $1 \%$ sodium tetraborate and $20 \%$ sucrose) and covered with a coverslip mounted with Araldite. The semi-thin sections were imaged using an Olympus BX-51 microscope and an Olympus CC12 camera setup.

Ultrathin sections were prepared with a Diatome Ultra $45^{\circ}$ diamond knife and were silver-interference colored (70-75 nm). They were placed on Formvar-covered, single-slot copper grids and stained with $2 \%$ uranyl acetate (E22400, Science Services) and 2.6\% lead citrate (E17810, Science Services) after Reynolds, in an automated TEM stainer (QG-3100, Boeckeler Instruments). The sections were examined and imaged using a ZEISS EM 10CR with digital imaging plates (Ditabis). Deviations from the standard TEM protocols described above are noted in Table 1. 
Table 1 List of studied species, collection information and the study method

\begin{tabular}{|c|c|c|c|c|}
\hline Taxon & Species & Sampling Info & Method & Note \\
\hline \multirow[t]{2}{*}{ Fabriciidae } & $\begin{array}{l}\text { Rubifabriciola tonerella (Banse, } \\
\text { 1956) }\end{array}$ & Aquarium-University of Bonn & CLSM, TEM & $\begin{array}{l}\text { COI Barcode Seq: GenBank } \\
\text { MT945946 } \\
\text { Specimen Voucher: SIO-BIC } \\
\text { A12935 }\end{array}$ \\
\hline & Fabricia stellaris (Müller, 1774) & $\begin{array}{l}\text { Lower intertidal, Isle of Heligo- } \\
\text { land, Laminaria holdfasts }\end{array}$ & TEM & TEM Buffer: Sodium cacodylate \\
\hline $\begin{array}{l}\text { Serpulidae } \\
\text { "Serpulinae" }\end{array}$ & $\begin{array}{l}\text { Spirobranchus triqueter (Lin- } \\
\text { neaus, 1758) }\end{array}$ & $\begin{array}{l}\text { Lower intertidal, Concarneau } \\
\text { (France) on stones }\end{array}$ & Histology, TEM & Histological stain: Azan \\
\hline "Serpulinae" & $\begin{array}{l}\text { Serpula vermicularis (Linneaus, } \\
\text { 1767) }\end{array}$ & $\begin{array}{l}\text { Mid intertidal, Roscoff (France), } \\
\text { Concarneau (France) on rocks }\end{array}$ & Histology, TEM & $\begin{array}{l}\text { Histological stain: Trichrome and } \\
\text { Azan }\end{array}$ \\
\hline Spirorbinae & $\begin{array}{l}\text { Spirorbis spirorbis (Linneaus, } \\
1758 \text { ) }\end{array}$ & $\begin{array}{l}\text { Mid intertidal, Isle of Helgoland, } \\
\text { Fucus phylloids }\end{array}$ & Histology, TEM, SEM & $\begin{array}{l}\text { Histological stain: Weigert's hae- } \\
\text { matoxylin, eosin TEM buffer: } \\
\text { sodium cacodylate }\end{array}$ \\
\hline $\begin{array}{l}\text { Sabellidae } \\
\text { Sabellinae }\end{array}$ & $\begin{array}{l}\text { Branchiomma bombyx (Dalyell, } \\
\text { 1853) }\end{array}$ & $\begin{array}{l}\text { Lower intertidal, Roscoff } \\
\text { (France), Laminaria holdfasts }\end{array}$ & $\begin{array}{l}\text { Histology, } \\
\text { TEM, SEM }\end{array}$ & $\begin{array}{l}\text { Histological stain: Trichrome and } \\
\text { Azan } \\
\text { TEM buffer: sodium cacodylate }\end{array}$ \\
\hline Sabellinae & $\begin{array}{l}\text { Sabella spallanzanii (Gmelin, } \\
\text { 1791) }\end{array}$ & $\begin{array}{l}\text { Sublittoral, Marina of Marseille } \\
\text { (France) }\end{array}$ & TEM & TEM buffer: sodium cacodylate \\
\hline Sabellinae * & Caobangia brandti Jones, 1972 & $\begin{array}{l}\text { Kaek River, Kaek Song, Thai- } \\
\text { land }\end{array}$ & TEM, SEM & $\begin{array}{l}\text { Specimen Voucher: SIO-BIC } \\
\text { A12936 }\end{array}$ \\
\hline Myxicolinae & Chone mollis (Bush, 1904) & La Jolla, CA & TEM & \\
\hline Myxicolinae & $\begin{array}{l}\text { Acromegalomma vesiculosum } \\
\text { (Montagu, 1813) }\end{array}$ & $\begin{array}{l}\text { Lower intertidal, Zostera } \\
\text { meadow } \\
\text { Roscoff (France) }\end{array}$ & Histology, TEM & \\
\hline Myxicolinae & Amphicorina sp. & La Jolla, CA & TEM, SEM & $\begin{array}{l}\text { Undescribed species } \\
\text { Specimen Voucher: } \\
\text { SIO-BIC A12937 }\end{array}$ \\
\hline
\end{tabular}

Vouchers, when available, deposited at the Benthic Invertebrate Collection of Scripps Institution of Oceanography (SIO-BIC). All sections are deposited at the histological collection of the Institute of Evolutionary Biology, Universtiy of Bonn

*The placement of Caobangia within Sabellinae is based on unpublished results of an upcoming phylogenomic study by the authors (Tilic et al. in prep.)

\section{Immunohistochemistry (IHC) and confocal laser scanning microscopy (CLSM)}

Multiple individuals of Rubifabriciola tonerella (Banse, 1959) were collected from the filter system of the seawater aquarium at the Institute of Evolutionary Biology in the University of Bonn. Individuals used for IHC were fixed in $4 \%$ paraformaldehyde in phosphate-buffered saline (PBS $0.01 \mathrm{M})$. The specimens were pre-incubated in a blocking solution of $10 \%$ normal goat serum in PBS with $0.2 \%$ Triton X-100 (Sigma Aldrich-T9284) for $3 \mathrm{~h}$ at room temperature. Primary antibody against acetylated $\alpha$-tubulin (Sigma Aldrich-T5186) was added into the blocking solution (1:200) and incubated overnight at $19{ }^{\circ} \mathrm{C}$. On the following day, the samples were washed three times for $15 \mathrm{~min}$ in PBS with $0.1 \%$ Triton. The specimens were then incubated with the secondary antibody (goat anti-mouse cy5, abcam-ab6563) (1:100) and phalloidin (Alexa Fluor ${ }^{\mathrm{TM}}$ 488; Thermo Fiscer-A12379) (1:150) for $2 \mathrm{~h}$ at $19^{\circ} \mathrm{C}$. Before staining nuclei with propidium iodide (SigmaAldrich-P4864) (1:200, $20 \mathrm{~min})$ the samples were treated with RNAse (Sigma Aldrich-R6513) (1:50, $30 \mathrm{~min}$ ). The stained samples were quickly dehydrated in isopropanol (1 $\min 70 \%, 1 \mathrm{~min} 85 \%, 1 \mathrm{~min} 95 \%, 1 \mathrm{~min} 100 \%, 1 \mathrm{~min}$ $100 \%$ ), cleared in three 5-min changes of Murray's Clear, mounted in Murray's Clear, and sealed with nail polish.

\section{Results}

\section{Fabriciidae}

The radiolar crowns of both fabriciid species studied, Fabricia stellaris (Müller, 1774) and Rubifabriciola tonerella (Banse, 1956), consist of three pairs of radioles with five to seven pinnules each (Fig. 3a, b). The radioles arise from two radiolar lobes. The pinnules and radioles terminate at about the same height and have the same width. In $R$. tonerella, two long ventral filamentous appendages that are as long as the radioles are present (Fig. 3b) and the dorsal margins of the radiolar lobes are separate (Fig. 3c). Laterally located large blood vessels and branchial hearts are present at the 
base of the radiolar lobes (Fig. 3c). The overall size of the radioles in $R$. tonerella were much smaller than in F. stellaris. The diameter of radioles in $R$. tonerella was $\pm 5.2 \mu \mathrm{m}$ and that of $F$. stellaris was $\pm 10.8 \mu \mathrm{m}$. The adoral epidermis of the pinnules and radioles are densely ciliated (Fig. 4a). Five rows of neighboring ciliated cells form the adoral ciliary band of radioles and pinnules in both species (Fig. 3d, $\mathrm{e}, \mathrm{g}$ ). These cells are prismatic with a basal position of the nucleus and contain high numbers of large, ovoid mitochondria (Fig. 3e). Besides these cells, the epidermis consists of cuboid non-ciliated cells. On the aboral side, some of the cuboid epidermis cells possess an elongated basal portion that contains myofibrils. The myofibrils extend parallel along the length of the radioles, so that these cells form the longitudinal muscles of the radioles (Fig. 4b, c). A circular orientation of the myofibrils was not found. These epitheliomuscle cells interdigitate and contain apico-basal bundles of intermediate filaments that extend into the basal portions. Here, hemidesmosomes attach the epithelio-muscle cells to the matrix (Fig. 4c). Epidermal gland cells are entirely missing.

A coelomic cavity extends inside of each radiole and branches into the pinnules. It does not extend into the center of the radiole or pinnule, but is slightly dislocated toward the ciliated cells. The coelomic cavity is lined by a simple myoepithelium consisting of flat cells with a few myofibrils only. These always run parallel to the longitudinal axis of the radiole or pinule, respectively.

Both the epidermis and the coelomic lining rest on a prominent extracellular matrix $(\mathrm{ecm})$. The expansion of this ecm implies that it makes up the supporting axis in both species. In transverse sections of radioles and pinnules, the $\mathrm{ecm}$ forms an asymmetric ring surrounding the coelomic cavity (Fig. 3f, g). The ecm is thicker underneath the aboral epidermis of each radiole and pinnule, and thinner underneath the adoral ciliated epidermis. In $F$. stellaris the aboral portion of the ecm measures up to $\pm 4 \mu \mathrm{m}$ in diameter in radioles and diminishes to $70 \mathrm{~nm}$ in the adoral portion (Fig. 3g, j). Such a crescent structure of the ecm in transverse sections of radioles is less obvious in $R$. tonerella. Here, the aboral ecm measures $\pm 0.88 \mu \mathrm{m}$ and diminishes to $\pm 0.18 \mu \mathrm{m}$ in thickness underneath the adoral epidermis. There is no evidence for larger fluid-filled spaces, blood lacunae or blood vessels inside the $\mathrm{ecm}$. The substructure of the $\mathrm{ecm}$ differs in both species. In $R$. tonerella, the ecm consists of densely and regularly arranged collagen fibers (Fig. 3d), whereas in F. stellaris the ecm appears less structured with a loose arrangement of collagen fibers (Fig. 3j).

In both species, the innervation is basiepithelial (Fig. 3f, $i, j$ ), though the number of neurites among the basal portions of the epidermis is higher than that underneath the coelomic myopithelium (Fig. 3f).
In $F$. stellaris, the cuticle of the unciliated aboral side is more densely arranged (Fig. 3h) and thicker than that of the ciliated oral side (Fig. $3 \mathrm{~g}$ ). In contrast, the cuticle of $R$. tonerella seemed to consist of only glycocalyx, and it was barely visible in between the microvilli of the epidermal cells (Fig. 3e).

\section{Serpulidae}

The radiolar crown of all three studied species has the characteristic arrangement of radioles originating from two distinct radiolar lobes on both sides of the mouth; rows of ciliated pinnules are attached to each radiole. In Serpula vermicularis (Linnaeus, 1767), the diameter of a radiole was $\pm 210 \mu \mathrm{m}$ (Fig. 5a), in Spirobranchus triqueter (Linnaeus, 1758) (Figs. 5d, 6c) and in Spirorbis spirorbis (Linnaeus, 1758) $\pm 116 \mu \mathrm{m}$ (Figs. 2a, 6a). In contrast to the two former medium-sized serpulids, S. spirorbis is a small species with a coiled calcareous tube (Fig. 1c). When alive, the crown protrudes out of the tube. A small specimen of about $1 \mathrm{~mm}$ coil diameter was fixed with a piece of the alga (Fucus sp.) it was attached to. It was subsequently decalcified and sectioned. When fixed the specimen retracted the radiolar crown, which thus is shown in its retracted condition in Fig. 5f, g.

All serpulids show the same general composition of radioles. The epidermis of the radioles consists of prismatic ciliated and non-ciliated epidermal cells, and gland cells (Figs. 5a, 6i-l). Gland cells are more abundant in the adoral portion of the epidermis. A variable number of ciliated cells form the adoral groove (Figs. 5a, 6e). These cells are elongate and densely ciliated. The $9 \times 2+2$ axonemata of these multiciliated cells each arise from a basal body that bears one up to $5 \mu \mathrm{m}$-long vertical and one up to $1.5 \mu \mathrm{m}$-long horizontal rootlet. The rootlets are interconnected and also connected to the intermediate filaments of the cell. This observation indicates that the cells are able to tolerate strong mechanical stress. Mitochondria are abundant in the apical section of the cell (Fig. 6k), the nucleus is medially or apically located (Fig. 5a, d).

Two different types of non-ciliated epidermal cells build up the lateral and aboral faces of radioles and pinnules, i.e., columnar cells reinforced with dense bundles of intermediate filaments, and vacuolated cells (Fig. 5c). The number and arrangement of these cells differs among the studied species. In $S$. spirorbis and $S$. triqueter, almost all epidermis cells are vesiculated (Figs. 5d, 6a, c), whereas the vesiculated cells form a cluster on either aboral side of a radiole in $S$. vermicularis (Fig. 5c). The vesiculated cells contain numerous large vesicles, their nucleus is dislocated to the margin of the cell and intermediate filaments are rare (Figs. $4 \mathrm{c}, 5 \mathrm{j}$ ). The number of these cells is much smaller than that of the elongate cells containing bundles of intermediate filaments. 

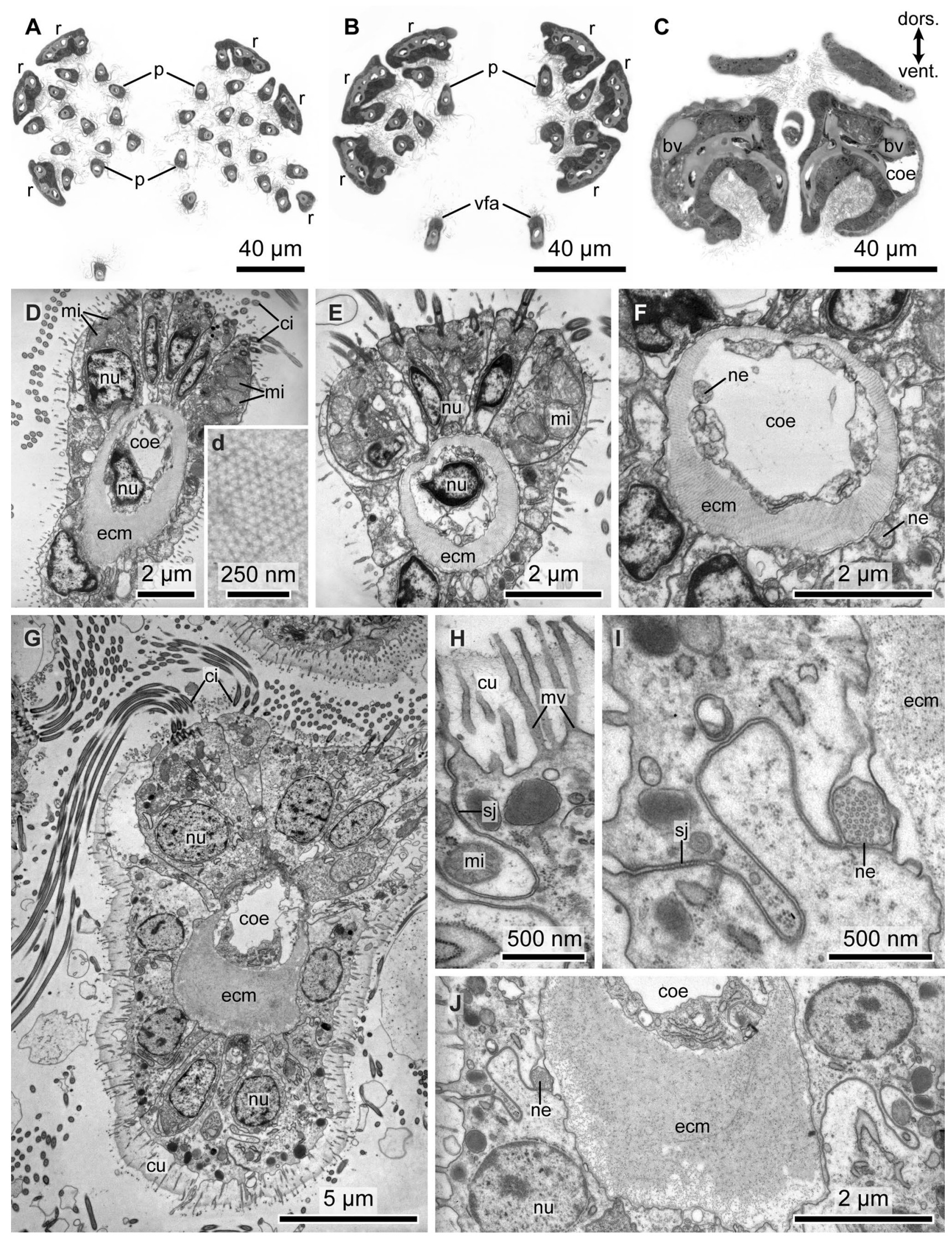
4Fig. 3 Fabriciidae. a-c Rubifabriciola tonerella series (distal to basal) of semi-thin cross sections of the radiolar crown showing the pinnules $(p)$ merging with the radioles $(r)$ and at the base forming the two radiolar lobes. d-f TEM of Rubifabriciola tonerella. $\mathbf{d}$ shows the substructure of the ecm ring in higher magnification. $\mathbf{g}-\mathbf{j}$ TEM of Fabricia stellaris. bv blood vessel, coe coelom, ci cilia, $c u$ cuticle, ecm extra-cellular matrix, $m i$ mitochondria, $m v$ microvilli, $n u$ nucleus $n e$ neurite, $s j$ septate junctions, $v f a$ ventral filamentous appendages

These cells, which comprise the majority of epidermal cells in S. vermicularis, are internally stiffened and stabilized by a strong cytoskeleton made up of intermediate filaments (Fig. 5a, c). These attach the apical microvilli to the thick cuticle (Fig. 5B), cross the cell and adhere to hemidesmosomes that are linked to the ecm (Fig. 6d). The nucleus of these cells is located apically. A few gland cells were found among these elongated, columnar epidermal cells.

In the serpulid species studied, the cuticle is well developed and contains collagen fibers that are arranged in a crosswise manner. The thickness of the cuticle varies among the species: variation is correlated to diameter of the radiole or pinule. The cuticle of the radioles in $S$. triqueter is $\pm 9.25 \mu \mathrm{m}$ thick, and that of radioles in $S$. vermicularis $\pm 20 \mu \mathrm{m}$. In the latter species, the cuticle is twice as thick where it is underlain by the tall cells containing strong bundles of intermediate filaments (Fig. 4a), compared to those regions underlain by vacuolated cells (Fig. 5c). A thin cuticle covers the ciliated cells.

Each radiole has a central coelomic cavity with a central blood vessel (Figs. 5a, d, 6a, 1). The coelomic cavity is horseshoe shaped in the transverse section and lined by a simple myoepithelium. The blood vessel is slightly dislocated to the aboral portion of the radiole or pinule. The vessel is lined by a perivascular ecm and contains electrondensely stained fluid and some cells containing a large irregular, lobate nucleus. These cells often seem to rest on the ecm but are never attached to it by junctional complexes. The perivascular $\mathrm{ecm}$ is continuous with the subepidermal $\mathrm{ecm}$. This continuity is responsible for the shape of the coelomic cavity that surrounds the blood vessel. The myoepithelial cells that rest on the coelomic face of the perivascular $\mathrm{ecm}$ contain circular myofibrils and form a muscle ring. During fixation for TEM studies, the myofibrils contracted. The perivascular ecm is therefore compressed and forms centrifugal electron-dense bars extending toward the inner part of the blood vessel. Contraction during fixation also reduced the diameter of the blood vessel and leads to the impression that the blood vessel is lined by an endothelium consisting of the above-mentioned cells. Two large bundles of longitudinal fiber muscle cells are located on either side of each radiole. Lateral and internal to the adoral groove, these longitudinal muscles are embedded in the subepidermal $\mathrm{ecm}$ (Figs. 5a, 6a, g, h). They are apposed to the coelomic lining without being part of it. The ecm lying between the muscle bundles is thicker than between the muscle and the coelothel (Figs. 5a, d, 6h).

Three neurite bundles were present in each radiole, one located centrally in between the two frontal muscle bundles underneath the subepidermal ecm (Fig. 5a, d) and two neurite bundles located abfrontally, directly at the base of the epidermis.

The pinnules of all serpulids show the same arrangement with a central coelomic cavity and aborally dislocated blood vessel. Only the adoral epidermis of the pinnules is ciliated, with longer cilia on either side and shorter central ones (Fig. 5b, e).

\section{Sabellidae}

The six species analyzed represent a wide variety of crown morphologies and size range observed in Sabellidae in both sabellid subclades, Sabellinae and Myxicolinae. The three species of Myxicolinae included in the study were Chone mollis (Bush, 1904), Acromegalomma vesiculosum (Montagu, 1813) and Amphicorina sp.

The $C$. mollis specimen had a cream-colored body and irregular reddish brown bands on the radioles, when alive. The total length of the branchial crown was about $10 \mathrm{~mm}$ and consisted of 16 pairs of radioles. Each radiole had lateral flanges and the main axis of a radiole was about $40 \mu \mathrm{m}$ in width (Fig. 8a). Amphicorina sp. had an adult body length of only $5 \mathrm{~mm}$. The radiolar crown consists of three radioles on each of the radiolar lobes and the diameter of each radiole is $\pm 20 \mu \mathrm{m}$ (Figs. 2b, 8n, o). The A. vesiculosum specimen had 24 pairs of radioles on semicircular radiolar lobes (Fig. 7g). Two of the radioles are modified distally to carry the compound radiolar eyes characteristic for the genus (Fig. 1b).

The three species of Sabellinae included in the study were Branchiomma bombyx (Dalyell, 1853), Sabella spallanzanii (Gmelin, 1791) and Caobangia brandti Jones, 1974. B. bombyx had 14 radioles on each radiolar lobe and a radiole diameter of $\pm 146 \mu \mathrm{m}$ measured at the base (Fig. 7a-e). The radioles are arranged in semicircles and a basal membrane joins the radioles (Fig. 7b, c). On the outer radiolar surface, there are paired stylodes (Figs. 2c, 7e, f). There are also paired compound eyes along each radiole (Figs. 7f, 8b). In $S$. spallanzanii, numerous radioles are arranged in whorled spirals. The radiolar lobes are asymmetric with a larger left and smaller right lobe. The sectioned specimen was a medium sized individual with a radiole diameter of $\pm 140 \mu \mathrm{m}$ measured at the base. $C$. brandti is a minute sabellid that burrows into the shells of freshwater snails. It has an aberrant body plan with a coiled gut and an anus opening near the head (Fig. 2d). The radiolar crown consists of three pairs of radioles in semicircular radiolar lobes (Fig. 2e). The diameter of a single radiole was $\pm 60 \mu \mathrm{m}$ (Fig. 9e). 
Fig. 4 Fabriciidae. Radiolar musculature. a, b Confocal images of Rubifabriciola tonerella showing the radiolar ciliation and musculature. Gray (anti $\alpha$-tubulin) cilia, blue (propidium iodide) nuclei, red (phalloidin) musculature. c TEM of Fabricia stellaris showing the epithelial muscle cells (arrowheads) with longitudinal myofibrils. ecm extracellular matrix, $n u$ nucleus
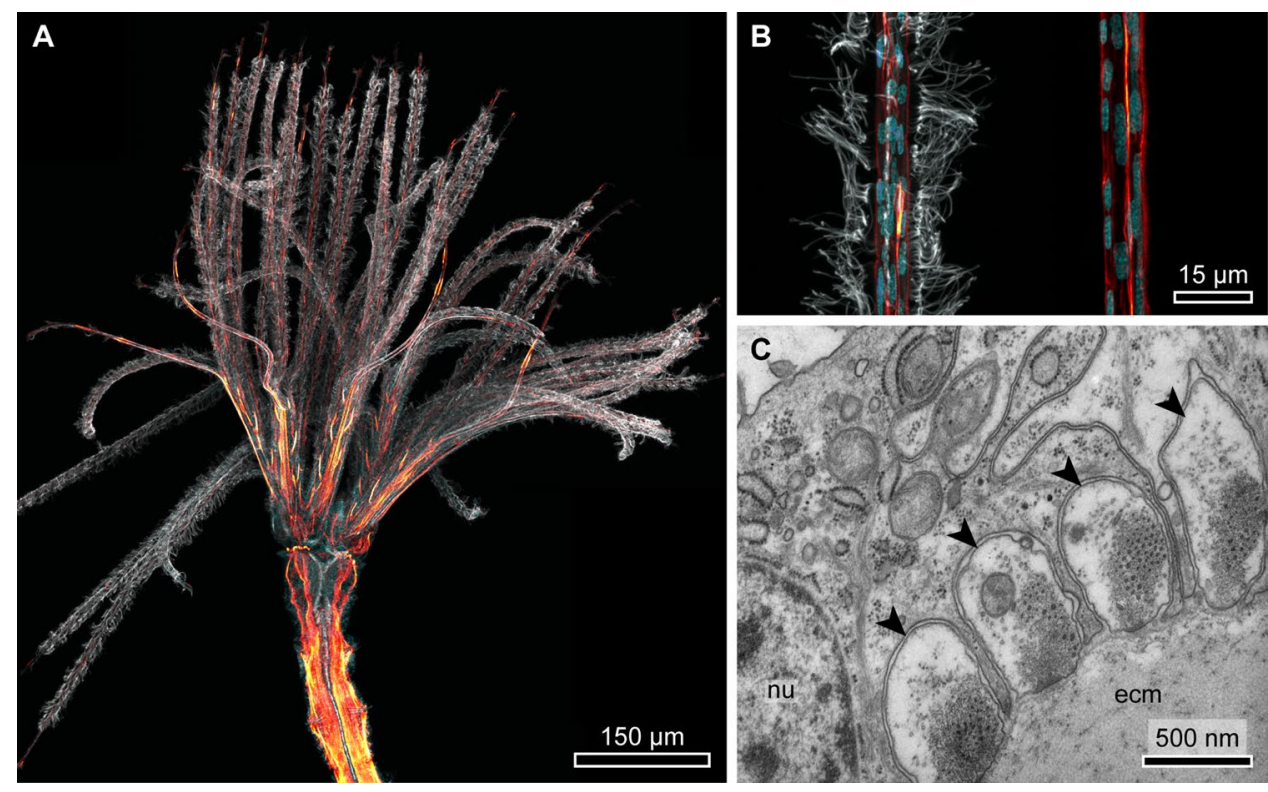

Regardless of the diversity of sabellids and crown morphologies represented in the study, the internal organization of the radioles was consistent. The radiolar epidermis of the examined sabellids consists of ciliated cells that make up the adoral groove (Figs. 8a, b, n, 9a, e), non-ciliated epidermal cells (Figs. 8a, c, n, 9a, e) and gland cells (Figs. 8d, 9a, b). The ciliated cells are prismatic and always multiciliated: their cilia insert in the cells with more than $3 \mu \mathrm{m}$-long vertical and up to $1.5 \mu \mathrm{m}$-long horizontal rootlets. The nucleus lies basally in the cell; several mitochondria are found next to the ciliary rootlets. The ciliated epidermis cells are covered by an electron-bright cuticle (Figs. 8e, 9a-c). The nonciliated cells are rather cuboid than prismatic and appear vesiculated by containing a subapical layer of numerous larger vesicles of about $1 \mu \mathrm{m}$ in diameter. The filling of the vesicles is not stainable and appears translucent in the electron microscope (Fig. 8b, c). Intermediate filaments pass the large vesicles while extending from the microvilli to the basal section of the cell and seem to keep the vesicles in place. Ciliated and non-ciliated cells differ, neither in thickness of the cuticle nor in the position of the nucleus. In A. vesiculosum the epidermal cells divert slightly from this general pattern. The vesicles form a thicker layer in the aboral section of the epidermis than in the remaining nonciliated cells (Fig. 7h). Underneath the vesicles, azan staining revealed a layer of brown pigments that are visible as electron-black stained large vesicles in electron microscopy. The nuclei are located underneath this layer. Intermediate filaments run from the inner of the microvilli that extend into the cuticle to the basal section of the cell, where they unite to form thicker bundles. These adhere to hemidesmosomes on the matrix side of the epidermis cell (Figs. 8h, 9c). In contrast to radioles, the aboral epidermis cells of pinnules are also multiciliated, so that pinnules have an oral and aboral ciliary band (Figs. 7i, 9e).

Underneath the adoral ciliary rim, a lateral pair of large longitudinal nerve cords extends down the longitudinal axis of the radiole. These nerve cords contain numerous neurites and a few nuclei. They are located within the subepidermal matrix between the epidermis and a large coelomic cavity and, thus, are retroperitoneal (Fig. 7e, h). The coelomic cavity is horseshoe shaped and surrounds a prominent blood vessel. The blood vessel is lined by a perivascular ecm and contains electron-gray stained fluid; blood cells were not seen. The perivascular ecm is continuous with the voluminous aboral ecm (Figs. 8c, j, 9f). This continuity explains the shape of the coelomic cavity that surrounds the blood vessel. The coelom consists of epithelio-muscle cells that rest on the subepidermal and the perivascular matrix. Those epithelio-muscle cells resting on the perivascular matrix show a circular arrangement of myofibrils that contracted during fixation. Due to contraction, the perivascular matrix is intensely folded (Fig. 8k). The remaining epithelio-muscles cells, i.e., those resting on the subepidermal matrix, show a longitudinal orientation of the myofibrils (Fig. 8i). Those next to the merger of both flanks of the horseshoe-shaped coelomic cavity show a higher amount of myofibrils, thus forming medio-lateral longitudinal muscle stands. There is a central blood vessel and a coelomic cavity in each pinnule (Figs. 7b, c, i, 8e). A voluminous aboral extracellular matrix underlies the blood vessel and the coelomic cavity.

In contrast to fabriciid species, this aboral ecm contains chordoid cells in varying numbers and arrangements. These chordoid cells form the supporting cellular axis, (sometimes referred to as "radiolar skeleton"), characteristic for all sabellid species. These chordoid cells are typical apolar cells, since 

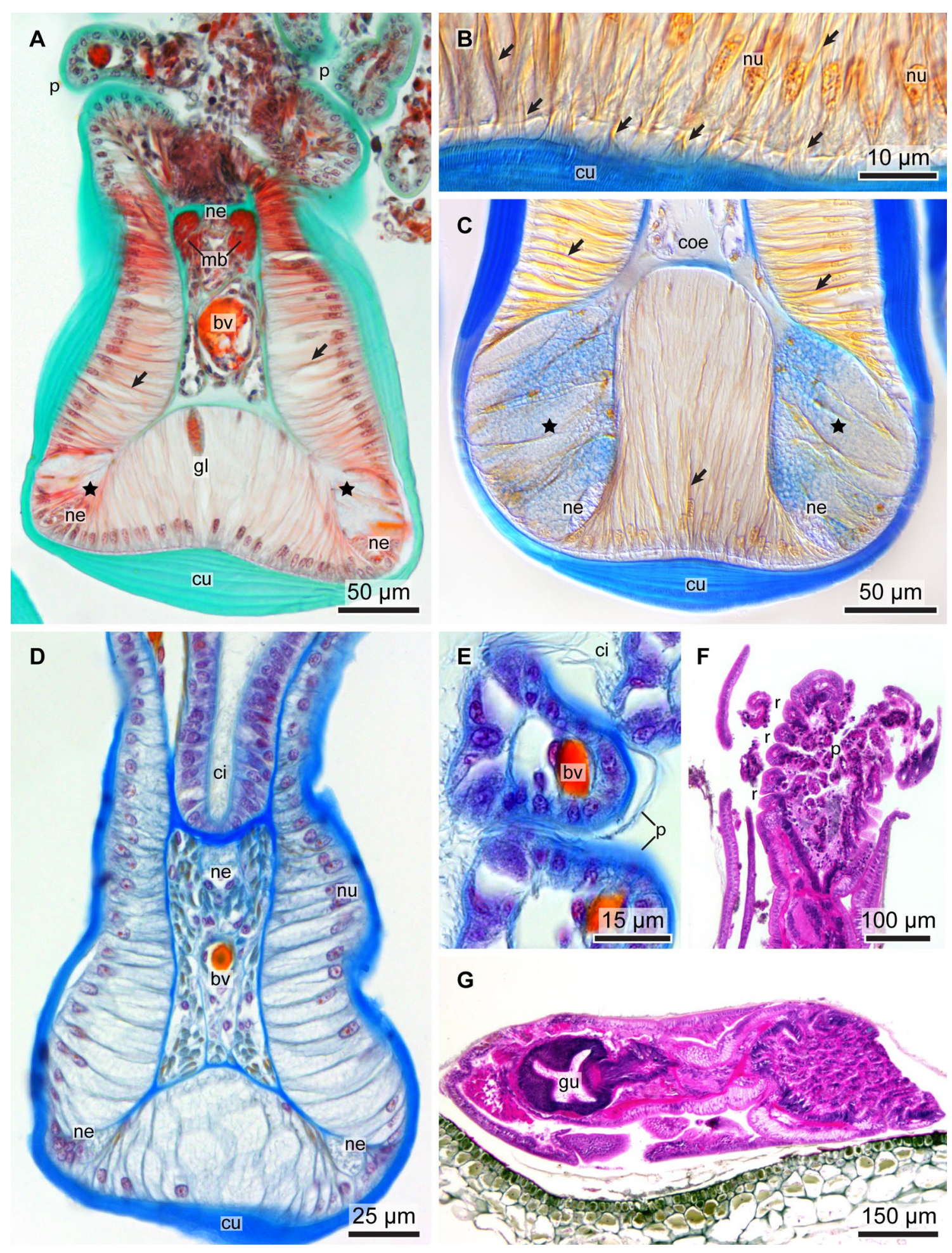

Fig. 5 Serpulidae. Histological sections of radioles $(r)$ and pinnules (p). a-c Serpula vermicularis, d, e Spirobranchus triqueter. f, g A complete decalcified specimen of Spirorbis spirorbis on alga. Arrows

mark the intermediate filaments, $b v$ blood vessel, coe coelom, $c i$ cilia, $c u$ cuticle, $g l$ gland cell, $g u$ gut, $m b$ muscle bundles, ne nerve, $n u$ nucleus, stars mark the lateral vesiculated cells

each cell is surrounded by an $\mathrm{ecm}$. The $\mathrm{ecm}$ surrounding the chordoid cells is denser than the remaining matrix and forms a strong extracellular "sheath" surrounding each chordoid cell, an envelope that increases in density toward the periphery (Fig. 8g, m). Each chordoid cell contains a large vacuole. The vacuole fills most part of the cell, so that the cytoplasm is 


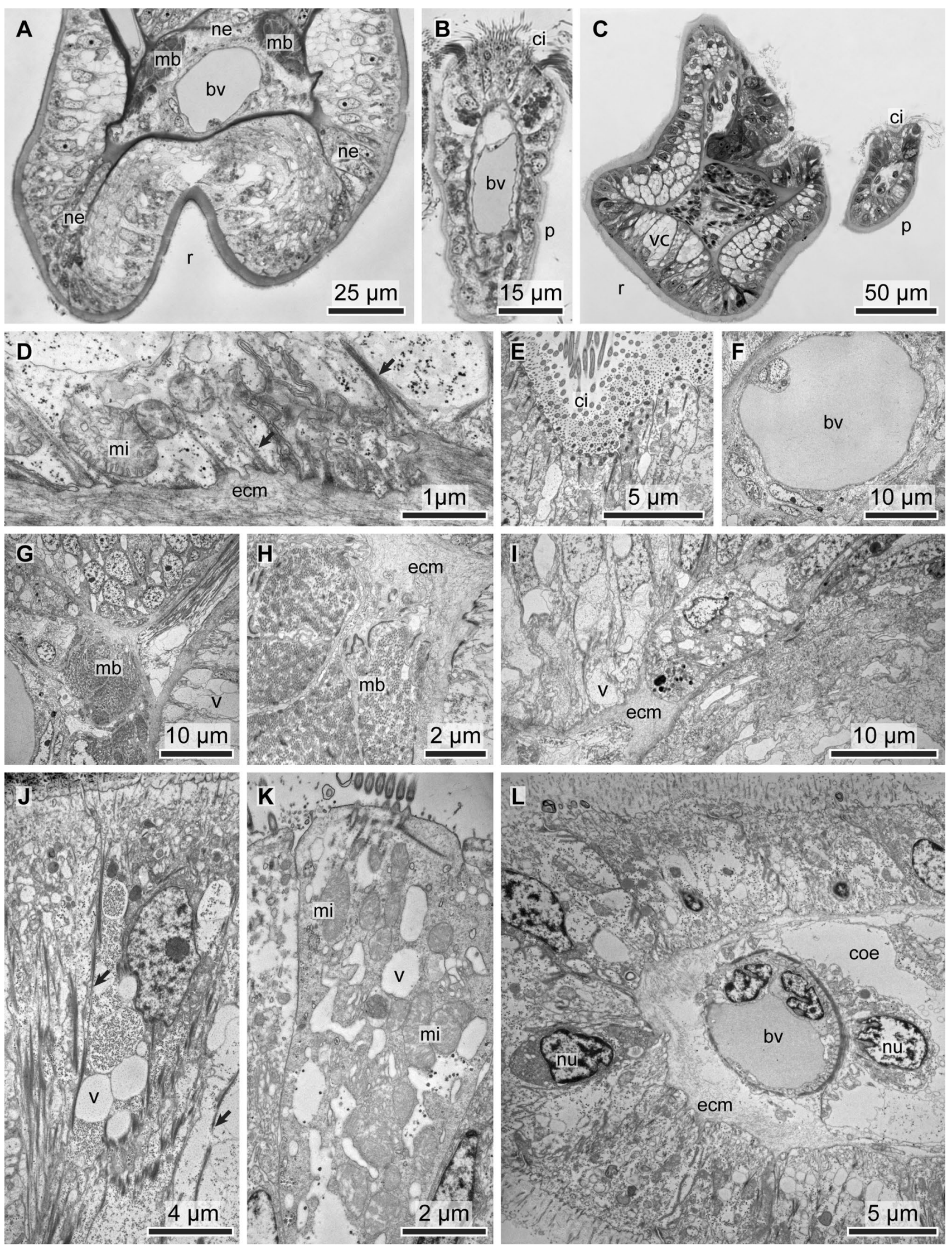


४Fig. 6 Serpulidae. Semi-thin cross sections of radioles $(r)$ and pinnules $(p)$. a, b Spirorbis spirorbis and c Spirobranchus triqueter. TEM of radioles and pinnules. d-i Spirorbis spirorbis, j-l Spirobranchus triqueter. Arrows mark the intermediate filaments, $b v$ blood vessel, coe coelom, $\mathrm{cu}$ cuticle, $\mathrm{ci}$ cilia, ecm extracellular matrix, $\mathrm{mb}$ muscle bundles, $m i$ mitochondria, $n u$ nucleus, ne nerve, $v$ vesicles of vesiculated epidermal cells

compressed to a small seam, merely bulging on the level of the heterochromatic nucleus. Beside the nucleus, the cytoplasm of the vacuolated chordoid cells contains very few mitochondria, few vesicles and almost no ER. While the diameter of the chordoid cells is species specific and varies between 20 and $40 \mu \mathrm{m}$, the cytoplasmic seam between cell membrane and vacuole membrane ranges between 100 and $750 \mathrm{~nm}$. The differences among the six sabellid species was mainly in the number and arrangement of the chordoid cells. In C. mollis and Amphichorina $\mathrm{sp}$., the supporting cellular axis of the radioles consisted of two cells per cross section, while their number is higher in the remaining species, except in $C$. brandti. The epidermal layers that form the lateral radiolar flanges in $C$. mollis consist mainly of the same vacuolated cells that line the aboral surface of the radiole.

Though $C$. brandti has the same overall arrangement of the radioles as in the other sabellid species, a single row of sequential chordoid cells makes up the aboral supporting axis of a radiole. The central coelomic cavity of the radioles is again horseshoe shaped and surrounds a blood vessel. The perivascular coelomic lining shows circularly arranged myofibrils (Fig. 9f). The ecm of the chordoid cells is much denser than the subepidermal matrix or the ecm surrounding the blood vessel (Fig. 9h).

The chordoid cells are susceptible for osmolarity and shrinking artifacts. Dubosque-Basil modification of the Bouin fluid for fixation contains $60 \%$ ethanol and may have led to strong shrinking artifacts in histology (Fig. 7e). The fixative used during preparing the animals for electron microscopy is adjusted to the salinity of seawater. But even here, the membrane surrounding the vacuoles is sometimes ruptured and cytoplasmic proteins are found inside the vacuole. Dehydration after postfixation of the animals may also have led to additional shrinking artifacts. Nevertheless, these artifacts indicate that the osmolarity inside the vacuole is higher than that of the surrounding, underpinning their assumed function as a semiskeletal element to reinforce the stability of the radioles and pinnules.

\section{Discussion}

\section{Comparison of the radiolar ultrastructure in Sabellida}

Our results and previously published accounts of radiole structure clearly indicate that there are distinct differences among the three major clades of Sabellida. However, the overall pattern and arrangement of radiolar tissues is conserved within each group.

Fabriciidae Except for an adoral ciliary rim, the epidermis is non-ciliated. The subepidermal matrix is asymmetrically distributed with respect to a central coelomic canal; its larger portion underlies the aboral epidermis. The ecm may or may not be internally fortified. There are no muscle fiber bundles or neural cords; instead, basiepithelial and basicoeloethial neurites are present as well as epithelio-muscle cells with a longitudinal arrangement of myofibrils (Fig. 10). Vesiculated epidermal cells and apolar, vacuolated, chordoid cells are missing. A radiolar blood vessel was missing in the studied fabriciids. However, Manayunkia, Echinofabricia and several other Fabriciidae have vascularized ventral filamentous appendages (Huang et al. 2011). Furthermore, in live Manayunkia green blood can sometimes be observed flowing through the radioles (pers. obs.). Until further examination of fabriciids from the Echinofabricia-Manayunkia clade, the ancestral condition with regard to the absence or presence of a radiolar blood vessel cannot be inferred.

Our description of the fabriciid radioles, and their internal stabilization, is in accordance with previous observations by Randel and Bick (2012). The radiolar structure in other fabriciids such as Manayunkia, Fabriciola and Augeneriella seem to show the same pattern (Zenkevitsch 1925; Hartmann-Schröder 1986; Fitzhugh 1989; Bick 2004). Lewis (1968) also illustrates a cross section of a radiole of Fabricia, but misinterpreted the central voluminous subepidermal $\mathrm{ecm}$ as a single chordoid cell labeled "cartilage" (Fitzhugh 1989). Rouse (1993, 1996c) also reported (and drew) a single cell wide "branchial skeleton", as present in Fabriciola baltica, F. liguronis, $F$. minuta and $F$. parvus. This appears to have been a misinterpretation. The images published in Rouse (1993; Fig. 28) also show what appears to be a thick ecm, rather than chordoid cells. Considering that our sampling of Fabriciidae spans the phylogeny of the group and the placement of Manayunkia as sister group to the remaining fabriciids (Huang et al. 2011; Tilic et al. 2020), it stands to reason that the general pattern described above applies to all Fabriciidae.

Serpulidae Except for an adoral ciliary rim, the epidermis is non-ciliated. In all serpulids the radiolar epidermis 

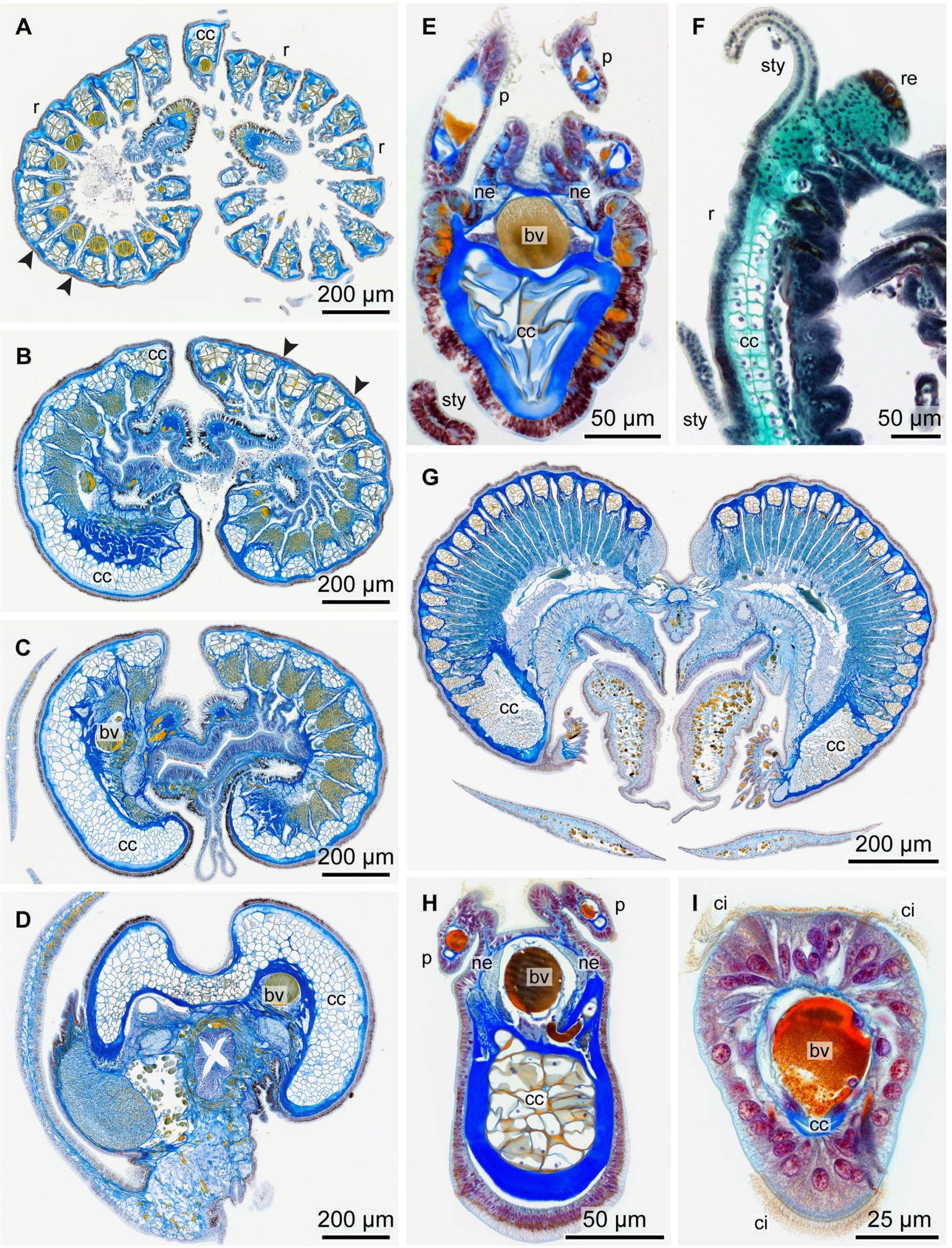
४Fig. 7 Sabellidae. Histological sections of radioles $(r)$ and pinnules ( $p$ ). a-f Branchiomma bombyx. Note the basal membrane (arrowheads) connecting the radioles in a and b. g-i Acromegalomma vesiculosum. $\mathbf{g}$ Cross section of the base of the radiolar crown. $\mathbf{h}$ Cross section of single radiole. $\mathbf{i}$ Cross section of a single pinnule. $b v$ blood vessel, $c c$ chordoid cells, $c i$ cilia, $g l$ gland cell, $n e$ nerve, $r e$ compound radiolar eye, sty stylode

cells are internally stabilized by dense intermediate filaments or densely packed large vesicles. The vesiculated cells either form paired strands on latero-aboral sides or they form the entire radiolar epidermis. Three neurite bundles are present: one below the ciliated groove and two abfronto-laterally. Two laterally arranged large longitudinal muscle fiber bundles are present at the base of the adoral groove, on either side of the nerve. A central coelomic cavity is present and a blood vessel bulges from the retroperitoneal $\mathrm{ecm}$ into the coelom. Myoepithelial circular muscles surround the blood vessel. The radiolar cuticle is thickened to serve as a stable attachment site to the cytoskeletal intermediate filaments (Fig. 10).

These observations are in accordance with Hanson's (1949) histological study of the serpulid crown and may be the same across Serpulidae. Rioja's (1929) statement of the presence of a "radiolar skeleton" as a primitive feature was shown by Fitzhugh (1989) to be a misinterpretation, based on Caullery and Mesnil's (1896) description of Josephella.

Sabellidae Except for an adoral ciliary rim, the epidermis is non-ciliated; in pinnules an additional aboral ciliary band is present. In all sabellids, the epidermis of radioles is composed mainly of vesiculated cells with intermediate filaments. Two subepidermal nerve cords are located frontolaterally. A central coelomic cavity is present and a blood vessel bulges from the retroperitoneal $\mathrm{ecm}$ into the coelom. Myoepithelial circular muscles surround the blood vessel. No muscle fiber bundles are present, but myocoelothelial cells with longitudinally arranged myofibrils. Apolar chordoid cells embedded in the ecm of the aboral radiolar axis form the cellular supporting axis of radioles and pinnules.

The chordoid cells are unique for Sabellidae and are regarded as being unique among invertebrates (Cole and Hall 2004a). Capa et al. (2011) discussed the inconsistent terminology used in the literature when referring to these cells, and suggest the term "supporting cellular axis" for the radiolar skeleton. We use the same term to describe the supporting axis and have chosen to use the term "chordoid cells" for describing its cells instead of "chondrocytes", since this term suggests an unwarranted similarity to the cartilage cells of vertebrates (Nicols 1931), a similiarity that is not even given in terms of chemical composition (Kukenberg 1881). Chordoid cell number and arrangement varies among sabellid species (Claparede 1873; Nicol 1931; Thomas 1940). Fitzhugh (1989) defined several character states to code these differences and established the number and arrangement of chordoid cells as a standard character in sabellid descriptions and generic diagnoses (Capa et al. 2019). Our data on the ultrastructure of the chordoid cells corroborate an earlier study of Kryvi (1977) and show that the structure of these cells is most likely identical across Sabellidae. Each of these cells contain a single large vacuole that compresses the cytoplasms to a small seam containing a few organelles only. A chordoid cell is surrounded by an ecm that is peripherally condensed, so that it seems to consist of two layers, one loosely organized hyaline and one electrondark, firm layer (Kryvi 1977, this paper). This ecm "sheath" can be separated from the cells (Viallanes 1885) and is sensitive to collagenase (Fitzharris 1976 for Sabella (=Bispira) melanostigma Schmarda 1861). Like Kryvi (1977), however, we were unable to confirm the existence of two different cell types in the supporting cellular axis of the radioles (Nicols 1931).

\section{Functional aspects of the radiolar tissues}

The supporting axis of the fabriciid species consists of an oral coelomic cavity and reinforced aboral $\mathrm{ecm}$ and that of serpulid species consists of only a central coelomic cavity. The vesiculated cells in the epidermis and the thickened cuticle may stabilize the radioles in serpulid species. In Sabellidae, the supporting axis consists of a coelomic cavity and at least a single row of sequential chordoid cells embedded in an $\mathrm{ecm}$. In sabellid species, these cells not only support the radioles and pinnules, but also the base of the radiolar lobes, dorsal radiolar lips and appendages (Capa et al. 2011).

All Sabellida possess a coelomic cavity or coelomic canal extending inside the radioles and branching into the pinnules. The coelomic lining consists of epithelio-muscle cells with a longitudinal fiber arrangement. If a blood vessel is present, the orientation of the perivascular epithelio-muscle cells is circular. Fluid filled cavities require muscular contraction to act as a hydroskeleton, so that it is rather costly to maintain stiffness for a longer period of time. Any nonmuscular internal stabilization mechanism might therefore be advantageous as long as flexibility or motility needed, for instance in case of a predator attack, is guaranteed.

Fabriciidae In the fabriciid species studied, muscularization is restricted to longitudinal fibers of the coelothelial and epidermal epithelio-muscle cells. Contractions of the coelomic epithelio-muscle cells should cause the radioles to bend toward the mouth. The strong and voluminous adoral matrix, however, is a non-muscular antagonist that erects the radiole and increases stiffness. The strong myoepithelial cells of the epidermis are restricted to the aboral portion of the radiole. Their contraction expands the radiolar crown and exposes the ciliated oral face of the radioles towards the water column. The antagonists are the reinforced aboral $\mathrm{ecm}$ as well as the oral coelomic cavity. Our assumption that the 


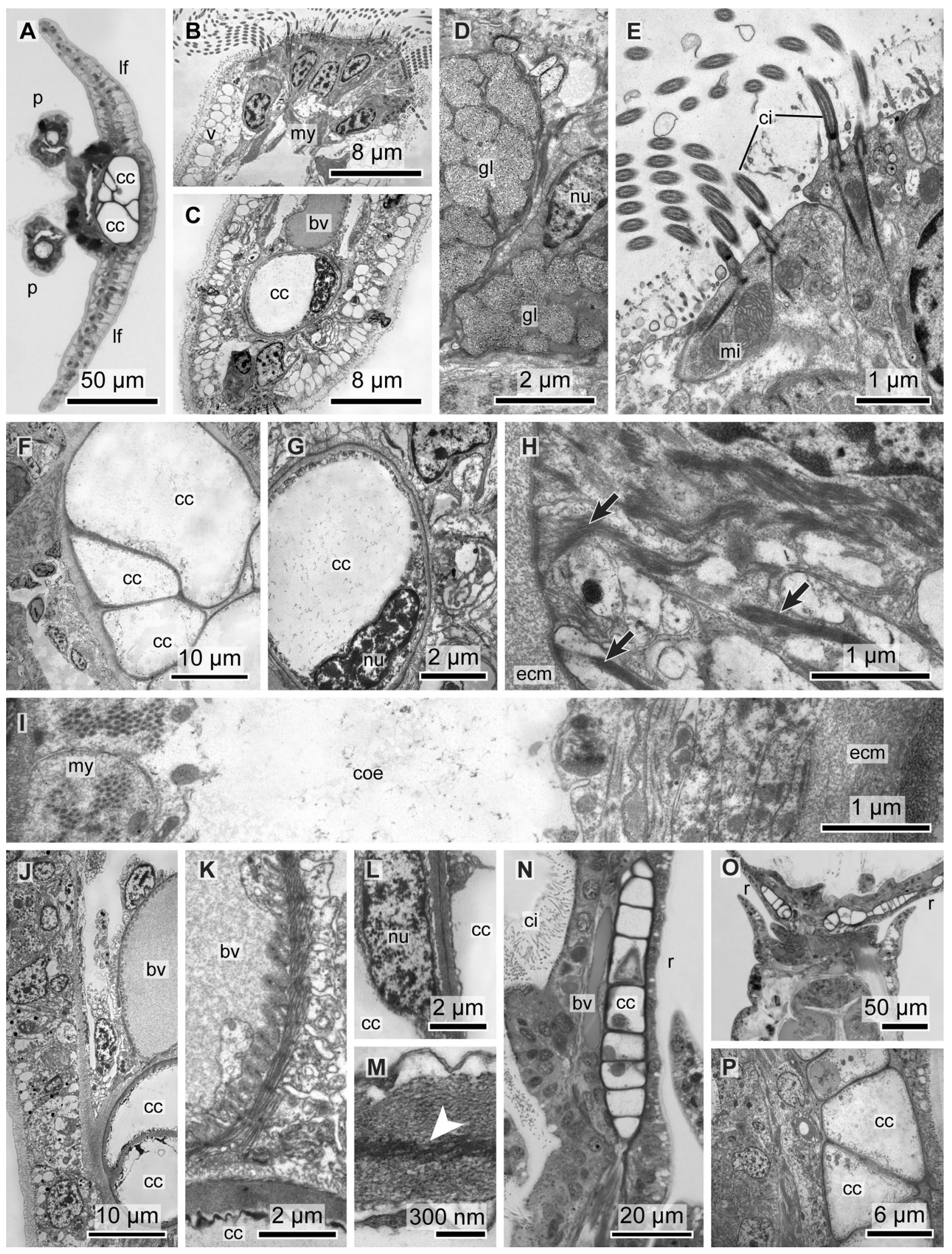


४Fig. 8 Sabellidae-Myxicolinae. a-h Chone mollis. Arrows in $\mathbf{h}$ mark the intermediate filaments attached to the ecm. $\mathbf{j}-\mathbf{m}$ Acromegalomma vesiculosum. Arrowhead in $\mathbf{m}$ marks the electron-dense layer of the amorphous chordoid cell matrix n-p Amphicorina sp. $b v$ blood vessel, $c c$ chordoid cells, $c i$ cilia, $g l$ gland cell, lf lateral flanges, $m i$ mitochondria, my myocoelothelial cells, $n u$ nucleus, $v$ vesicles of vesiculated epidermal cells

ecm primarily serves as a non-muscular antagonist is corroborated by the observation that the ecm in smaller species, like Rubifabriciola tonerella, shows a regular fiber arrangement. This might compensate for spatial limitation of the ecm in smaller species to maintain its antagonistic function. The structure of the radiole is highly adapted to rapid folding and unfolding the radiolar crown like an umbrella. Bending of the radioles is only possible where the aboral ecm is less voluminous and lacks fiber patterning and is restricted to the tips of the radioles. The ecm can therefore largely guarantee full expansion of the radiolar crown and thus keep this condition at almost no energy costs.

Serpulidae In all serpulid species, the radiolar musculature consists of a pair of thick adoral muscle strands as well as of epithelio-muscle cells of the coelomic lining with a longitudinal and circular fiber arrangement. Contraction of the muscle strand bends the radiole, and the coelom canal could act as antagonist together with the reinforced cuticle and the vesiculated cells. The blood vessels inside radioles and pinnules indicate respiratory function of the radiolar crown, a function that is potentially in conflict with the thickened cuticle that reduces diffusion. Although a thick cuticle is basically a powerful antagonist to muscular contraction, vesiculated cells are probably a trade-off to maintain antagonistic function while facilitating respiration. This assumption is corroborated by the observation that a thickened cuticle is found in larger species only and restricted to the lateral and aboral face of the radiole. In these species, vesiculated cells are restricted to a pair of latero-aboral strands, while this cell type forms almost the entire epidermis in the small spirorbin species. We expect that a similar situation is found in the small Salmacina and Filograna species. In contrast to Fabriciidae, radiole morphology in Serpulidae indicates that rapid retraction and bending of the radioles is caused by the adoral muscle strands. Full expansion of the crown is caused by vesiculated cells and a thick cuticle, potentially supported by coelomic pressure. The function of the latter, however, may be restricted to only guarantee the contraction of the blood vessel. When this is the case, expansion of the radiolar crown would cost almost no energy.

Sabellidae In the sabellid species, the radiolar musculature consists of epithelio-muscle cells of the coelomic lining with a longitudinal and circular fiber arrangement. The former are more prominent on the adoral face, next to the supporting cellular axis. Contraction of these musculature will at best slightly bend the tip of the radioles, because the adoral $\mathrm{ecm}$ with the chordoid cells causes extreme stiffness of the radioles. Motility in terms of an umbrella-like folding of the tentacle crown is caused by strong muscle bundles at the base of the radioles (shown in Fig. 7a-d for Branchiomma bombyx). The chordoid cells that build up the radiolar skeleton are extremely efficient in maintaining full expansion of the crown at almost no energy cost, but at the price of almost no mobility of a single radiole. Like in serpulids, the blood vessels inside radioles and pinnules indicate respiratory function of the radiolar crown. The perivascular coelomic lining consists of myoepithelial cells with a circular fiber orientation. The function of the coelom may thus rather guarantee contraction of the blood vessel than counteracting the stiffness of the supporting cellular axis.

\section{Phylogenetic implications}

Exposing the adoral ciliated bands to the water for suspension feeding at low costs lead to different solutions in all three groups. We will infer the evolution of radiolar tissues from the structural and functional consideration by using the most recent phylogeny of Sabellida as a backbone (Tilic et al. 2020), where Sabellidae and Serpulidae are sister taxa with Fabriciidae the sister to these. Spionidae and Sabellariidae are the outgroups, and the bilobed radiolar crown is not only homologous within Sabellida but is also considered homologous to the palps of other annelids like Spionidae and Sabellariidae (Orrhage 1980; Rouse and Fauchald 1997). This homology implies that common ancestors along the stem lineage for Sabellida must have had at least a pair of anterior palp-like appendages. Since all extant Sabellida possess a crown consisting of radioles with pinnules, it is likely that the most recent common ancestor of Sabellida already had such structures. This statement implies that all radioles and pinnules are homologous, irrespective of difference in number, branching pattern and structure (Randel and Bick 2012). Morphological differences of the radiolar crown must accordingly be considered transformations rather than independently evolved structures. Not all aspects of the nature of the ancestral crown are clear.

A coelomic cavity is located in the center of each radiole and is reasonably inferred as plesiomorphic for Sabellida. In larger fabriciids and in sabellids, the major portion of the ecm is found aborally. In the latter, chordoid cells are embedded into this matrix. Whereas the chordoid cells form a clear apomorphy for Sabellidae, a matrix that is asymmetrical 


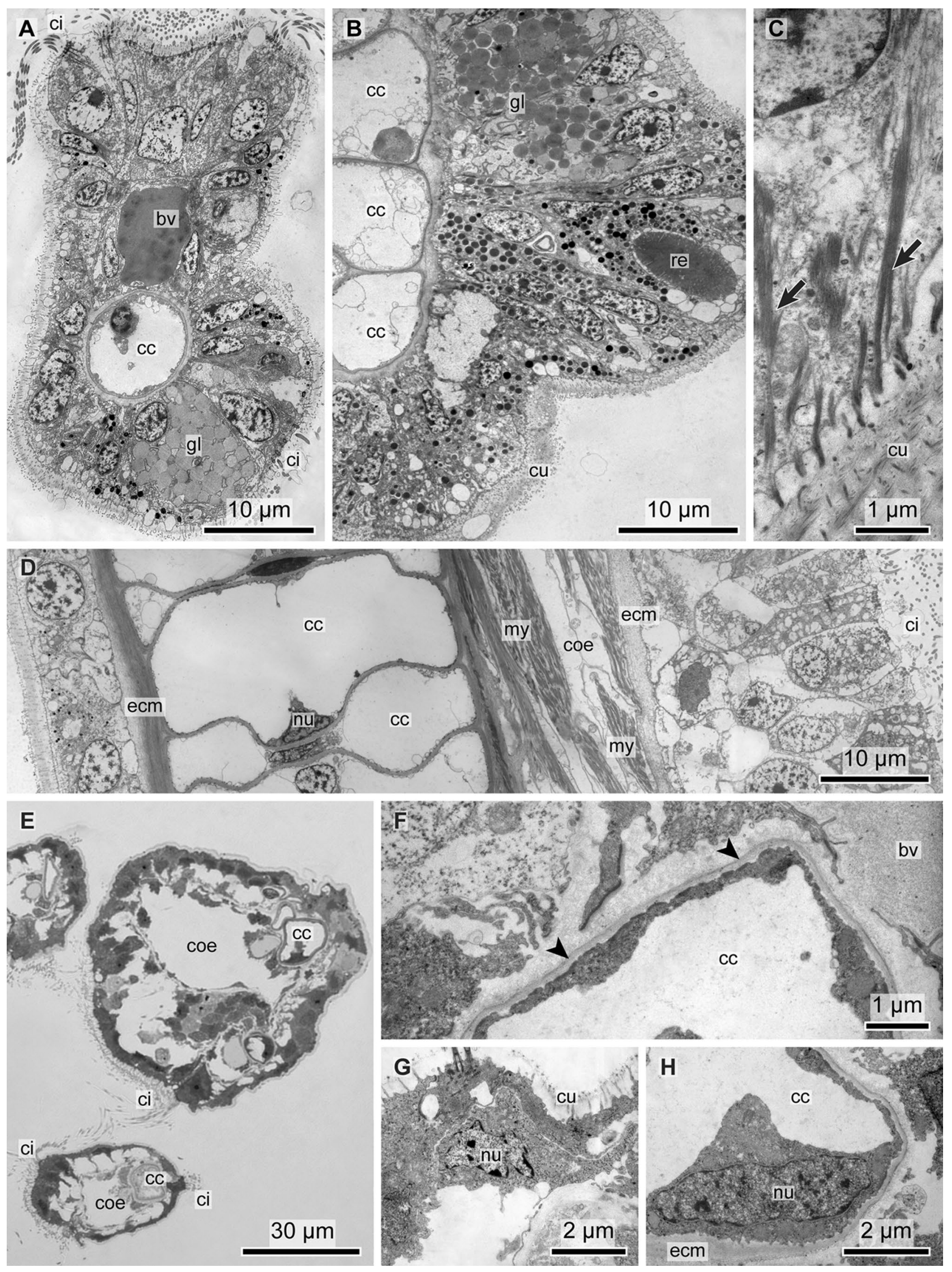


4Fig. 9 Sabellidae-Sabellinae. a, b Branchiomma bombyx. c, d Sabella spalanzanii. e-h Caobangia brandti. Arrowheads in $\mathbf{f}$ mark the electron-dense layer of the amorphous chordoid cell matrix. Arrows mark the intermediate filaments, $b v$ blood vessel, $c c$ chordoid cells, $c i$ cilia, coe coelom, $c u$ cuticle, ecm extra-cellular matrix, $g l$ gland cell, $m i$ mitochondria, my myocoelothelial cells, re radiolar eye, $n u$ nucleus, $v$ vesicles of vacuolated epidermal cells with respect to the coelom and more voluminous on the aboral face of the radiole is present in Sabellidae and Fabriciidae and missing in Serpulidae. This goes along with utilizing different structural elements to maintain stiffness (ecm, epidermis cells, cuticle) and evolving a new cell type, the chordoid cells.
Fig. 10 Radiolar tissues in Sabellida shown on the tree topology after Tilic et al. 2020. The schematic illustrations show the general pattern seen in the radioles for each clade on the basis of chosen representative species
FABRICIIDAE

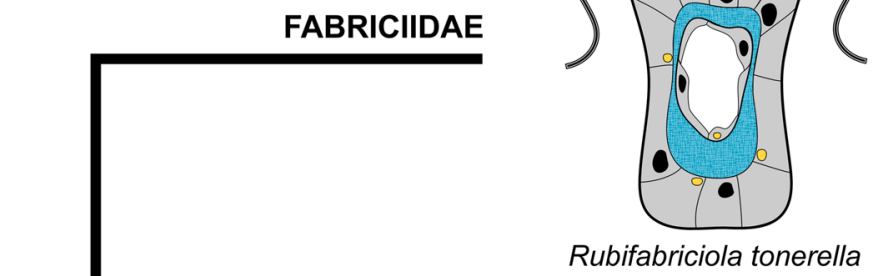

SERPULIDAE

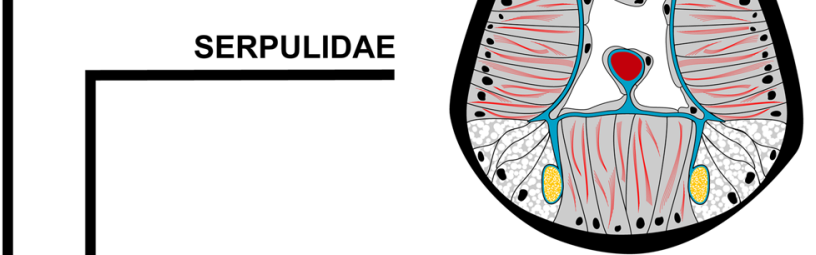

Serpula vermicularis

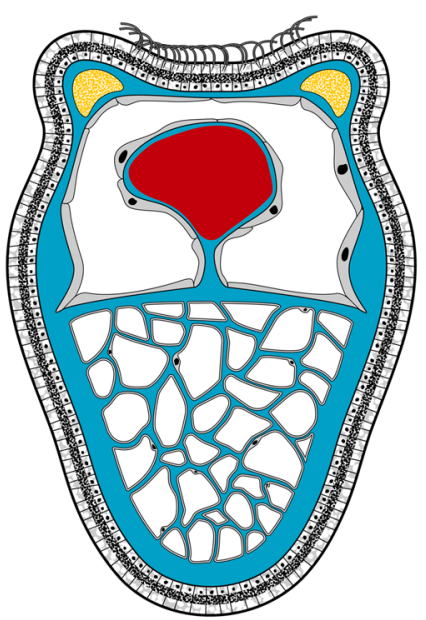

Acromegalomma vesiculosum

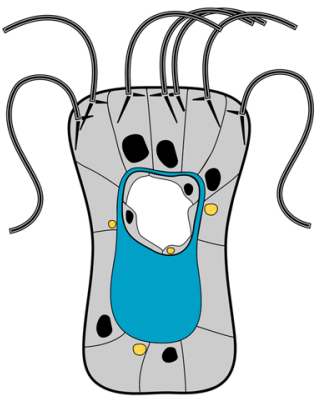

Fabricia stellaris

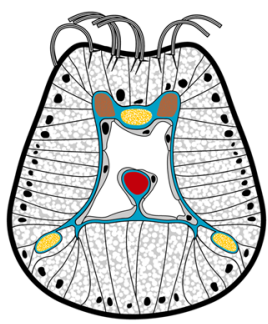

Spirorbis spirorbis

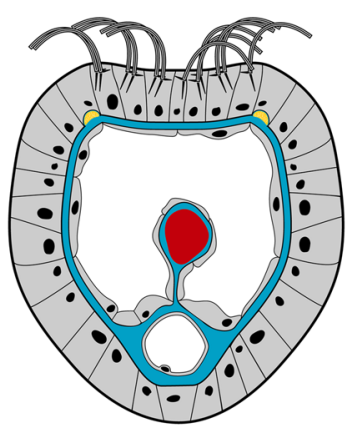

Caobangia brandti 
Acknowledgements We would like to thank the laboratory technicians of the Institute of Evolutionary Biology at the University of Bonn for their support with the preparation of samples used in this study: Claudia Müller, prepared the CLSM samples of Rubifabriciola tonerella and imaged some of the TEM and histological sections. Tatjana Bartz prepared some of the ultra-thin sections and imaged these with the EM10. Christiane Wallnisch prepared some of the paraffin sections. Our thanks are also due to the staff of the "Station marine de Concarneau" for their hospitality and continuous support over many years of repeated field trips that made most of our sampling possible. We would also like to acknowledge Charlotte Seid (SIO-BIC) for her help with organizing deposited voucher specimens. Caobangia brandti collections were supported by the Australian Research Council funds to GWR. ET was supported by a personal postdoc fellowship of the German Research Foundation, DFG (TI 973/1-1).

Funding Open Access funding enabled and organized by Projekt DEAL.

\section{Compliance with ethical standards}

Conflict of interest All three authors declare that they have no conflicts of interest.

Ethical approval We neither used endangered species nor collected animals from protected areas and we followed all applicable international, national and/or institutional guidelines for the care and use of animals.

Open Access This article is licensed under a Creative Commons Attribution 4.0 International License, which permits use, sharing, adaptation, distribution and reproduction in any medium or format, as long as you give appropriate credit to the original author(s) and the source, provide a link to the Creative Commons licence, and indicate if changes were made. The images or other third party material in this article are included in the article's Creative Commons licence, unless indicated otherwise in a credit line to the material. If material is not included in the article's Creative Commons licence and your intended use is not permitted by statutory regulation or exceeds the permitted use, you will need to obtain permission directly from the copyright holder. To view a copy of this licence, visit http://creativecommons.org/licenses/by/4.0/.

\section{References}

Bick A (2004) Redescription of Pseudoaugeneriella nigra (Langerhans, 1880), new combination (Polychaeta, Sabellidae), with remarks on some characters of Fabriciinae. Zool Anz 243:53-63. https://doi.org/10.1016/j.jcz.2004.06.003

Bok MJ, Capa M, Nilsson D-E (2016) Here, there and everywhere: the radiolar eyes of fan worms (Annelida, Sabellidae). Integr Comp Biol 56:784-795. https://doi.org/10.1093/icb/icw089

Bok MJ, Porter ML, Ten Hove HA et al (2017) Radiolar eyes of serpulid worms (Annelida, Serpulidae): structures, function, and phototransduction. Biol Bull 233:39-57. https://doi. org/10.1086/694735

Bonar DB (1972) Feeding and tube construction in Chone mollis Bush (polychaeta, sabellidae). J Exp Mar Bio Ecol 9:1-18. https://doi. org/10.1016/0022-0981(72)90002-0

Capa M, de Matos Nogueira JM, Rossi MCS (2011) Comparative internal structure of dorsal lips and radiolar appendages inSabellidae (Polychaeta) and phylogenetic implications. J Morphol 272:302-319. https://doi.org/10.1002/jmor.10914
Capa M, Giangrande A, Nogueira JMM, Tovar-Hernández MA (2019) 7.4.6 Sabellidae Latreille, 1825. In: Purschke G, Böggemann M, Westheide W (eds) Annelida - Volume 2: Pleistoannelida, Sedentaria II. De Gruyter, pp 164-212

Caullery M, Mesnil F (1896) Note sur deux serpuliens nouveaux: Oriopsis metchnikowi n. g., n. sp. et Josephella marenzelleri n. g., n. sp. Zool Anz 10:482-486

Cole AG, Hall BK (2004a) The nature and significance of invertebrate cartilages revisited: distribution and histology of cartilage and cartilage-like tissues within the Metazoa. Zoology 107:261-273. https://doi.org/10.1016/j.zool.2004.05.001

Cole AG, Hall BK (2004b) Cartilage is a metazoan tissue; integrating data from nonvertebrate sources. Acta Zool 85:69-80. https://doi. org/10.1111/j.0001-7272.2004.00159.x

Dales RP (1962) The polychaete stomodeum and the interrelationships of the families of the Polychaeta. Proc Zool Soc Lond 139:289328. https://doi.org/10.1111/j.1469-7998.1962.tb01837.x

Fauchald K (1977) The polychaete worms: definitions and keys to the orders, families and genera. Natural History Museum of Los Angeles County Los Angeles, Los Angeles

Fitzhugh K (1989) A systematic revision of the Sabellidae-Caobangiidae-Sabellongidae complex (Annelida: Polychaeta). Bull Am Mus Nat Hist 192:1-104

Fitzsimons G (1965) Feeding and tube-building in Sabellastarte magnifica (Shaw) (Sabellidae:Polychaeta). Bull Mar Sci 15:642-671

Goffredi SK, Tilic E, Mullin SW et al (2020) Methanotrophic bacterial symbionts fuel dense populations of deep-sea feather duster worms (Sabellida, Annelida) and extend the spatial influence of methane seepage. Sci Adv 6:eaay8562. https://doi.org/10.1126/ sciadv.aay 8562

Hanson J (1949) Observations on the branchial crown of the Serpulidae (Annelida, Polychaeta). J Cell Sci s3-90:221-233

Hartmann-Schröder G (1986) Polychaeta (incl. Archiannelida). Stygofauna mundi A faunistic, distributional and ecological synthesis of the world fauna inhabiting subterranean waters (including the marine interstitial) EJ Brill, Leiden, Netherlands 210-233

Huang D, Fitzhugh K, Rouse GW (2011) Inference of phylogenetic relationships within Fabriciidae (Sabellida, Annelida) using molecular and morphological data. Cladistics 27:356-379. https ://doi.org/10.1111/j.1096-0031.2010.00343.x

Krukenberg CFW (1882) Vergleichend-physiologische Studien an den Küsten der Adria; experimentelle Untersuchungen. Carl Winter's Universitätsbuchhandlung, Heidelberg

Kryvi H (1977) The fine structure of the cartilage in the annelid Sabella penicillum. Protoplasma 91:191-200. https://doi.org/10.1007/ BF01276733

Kupriyanova EK, Rouse GW (2008) Yet another example of paraphyly in Annelida: molecular evidence that Sabellidae contains Serpulidae. Mol Phylogenet Evol 46:1174-1181. https://doi. org/10.1016/j.ympev.2007.10.025

Lewis DB (1968) Some aspects of the ecology of Fabricia sabella (Ehr.) (Annelida, Polychaeta). J Linn Soc London, Zool 47:515526. https://doi.org/10.1111/j.1096-3642.1968.tb00550d.x

Minuth WW, Denk L (2015) Advanced fixation for transmission electron microscopy unveils special extracellular matrix within the renal stem/progenitor cell niche. Methods Mol Biol 1212:21-37. https://doi.org/10.1007/7651_2014_93

Nicol E (1931) The feeding mechanism, formation of the tube, and physiology of digestion in Sabella pavonina. Earth Environ Sci Trans R Soc Edinb 56:537-598. https://doi.org/10.1017/S0080 456800016495

Pillai TG (1970) Studies on a collection of Spirorbids from Ceylon, together with a critical review and revision of Spirorbid systematics, and an account of their phylogeny and zoogeography. Ceylon J Sci (Biological Sciences) 8(2):100-172 
Randel N, Bick A (2012) Development, morphology and ultrastructure of the branchial crown of Fabricia stellaris (Müller, 1774)(Polychaeta: Sabellida: Fabriciinae). Acta Zool 93:409-442. https://doi. org/10.1111/j.1463-6395.2011.00515.x

Rouse GW (1993) New Fabriciola species (Polychaeta, Sabellidae, Fabriciinae) from the eastern Atlantic, with a description of sperm and spermathecal ultrastructure. Zool Scr 22:249-261. https://doi. org/10.1111/j.1463-6409.1993.tb00356.x

Rouse GW (1995) Spermathecae of Fabricia and Manayunkia (Sabellidae, Polychaeta). Invertebr Biol 114:248-255. https://doi. org/10.2307/3226879

Rouse GW (1996a) Variability of sperm storage by females in the Sabellidae and Serpulidae (Polychaeta, Sabellida). Zoomorphology 116:179-193. https://doi.org/10.1007/BF02527158

Rouse GW (1996b) A new species of Perkinsiana (Sabellidae, Polychaeta) from Papua New Guinea; with a description of larval development. Ophelia 45(2):101-114. https://doi. org/10.1080/00785326.1996.10432465

Rouse GW (1996c) New Fabriciola and Manayunkia species (Fabriciinae: Sabellidae: Polychaeta) from Papua New Guinea. J Nat Hist 30:1761-1778. https://doi.org/10.1080/00222939600771031
Smith RS (1991) Relationships within the order Sabellida (Polychaeta). Ophelia Suppl 5:249-260

Tilic E, Sayyari E, Stiller J et al (2020) More is needed-Thousands of loci are required to elucidate the relationships of the "flowers of the sea"(Sabellida, Annelida). Mol Phylogenet Evol. https://doi. org/10.1016/j.ympev.2020.106892

Viallanes MH (1885) Sur la structure squelette branchial de la sabelle. Annales des sciences naturelles Paris 6

Viallanes MH (1886) Sur le tissu cartilagineux de la Sabelle. Bulletin de la société philomathique de Paris 7:6-8

Zenkevitsch LA (1925) Biologie, Anatomie und Systematik der Süsswasserpolychaeten des Baikalsees. Zoologische Jahrbücher, Abteilung für Systematik, Ökologie und Geographie der Tiere 50:1-60

Publisher's Note Springer Nature remains neutral with regard to jurisdictional claims in published maps and institutional affiliations. 